\title{
Influence of Urbanization on Water Quality of Wadi El-Arab Catchment Area- Jordan
}

\author{
Rakad A. Ta'any 1
}

\begin{abstract}
This research paper deals with the hydrological and hydrochemical and bacteriological characteristics of Wadi El-Arab catchment area. The study area covers an area of about $267 \mathrm{~km}^{2}$ and lies between $208-230$ East, and 210230 North (Palestine Grid). The outcropping rocks in the area are sedimentary rocks of the Upper Cretaceous, Lower Tertiary and Recent deposits. The average annual rainfall in the whole catchment area ranges between less than $200 \mathrm{~mm}$ to more than $800 \mathrm{~mm}$. The runoff ranges between 1.44 million cubic meters (MCM) to 72.89 MCM. A dam was constructed on Wadi El-Arab catchment area in 1987, with a total capacity of about $20 \mathrm{MCM}$ to collect flood and base flow for irrigation in the Jordan Valley area. There are more than $\mathbf{2 0}$ groundwater wells were drilled in the catchment area and six major springs; most of the wells water are used for irrigation purposes. The average discharge of the springs ranges between $0.81 \mathrm{~m}^{3} / \mathrm{h}$ and $592.2 \mathrm{~m}^{3} / \mathrm{h}$ and the yield of the wells range between 3 $\mathrm{m}^{3} / \mathrm{h}$ and $6000 \mathrm{~m} 3 / \mathrm{h}$. Water samples from the six springs and seven wells have been collected to study the influence of Irbid Wastewater Treatment Plant (WWTP) effluent on the groundwater quality and to classify the water of springs and wells quality according to their chemical composition furthermore, to study the quality of the springs and wells chemistry and bacteriologically. The results show that the chemical constituents and physical parameters of the studied springs and wells are within the permissible limits according to the World Health Organization (WHO) and Jordan Standards, and they are suitable for domestic and drinking water purposes. The classification of springs and wells water based on hardness: all springs and wells are classified as very hard water. According to the U.S Salinity Laboratory Classification, the springs and wells water were classified into two groups: Barruqa, Wadi Zahar Springs and Wadi El-Arab Well (6) are classified as $\mathrm{C}_{2}-\mathrm{S}_{1}$ while other springs and wells are classified as $\mathrm{C}_{3}-\mathrm{S}_{1}$. The bacteriological analyses indicate that the studied wells are non-polluted by total coliform and faecal coliform.
\end{abstract}

Keywords: Hydrological, bacteriological, El - Arab catchment, groundwater, dam.

\section{INTRODUCTION}

The naturally imposed semi-aridity of Jordan entails the country in limited amounts of rainfall and hence limited surface and groundwater resources. During the last few decades population growth, industrialization projects and improving standards of living not have led to increasing water use and over exploitation, but also to deteriorating water qualities as a result of the various human activities .Due to all of this a critical need for more drinking water is born,( MWI, 2011).

Water resources in Jordan are scarce and expensive to exploit. More than $80 \%$ of Jordan receives an annual average rainfall of less than $100 \mathrm{~mm}$ (Ta'any and AlZu'bi, 2007). Surface water resources are very limited and depend on rainfall as the major water source. Water resource planning and allocation involve increasing difficult choices between the requirements of competing users. Municipal and industrial water requirements have increased sharply, as the population has increased and increasing urbanization and rising incomes have brought increased demands for water.

Pollution is considered as the most important problem facing the world in general and Jordan in particular long time ago. This issue is still increasing to be at the top of all problems, which needs a scientific solution as soon, as possible to protect the water resources and the surrounded environment. Surface and groundwater are largely polluted, because of the dramatic life development particularly the industrial aspects (Haddadin, 2005).

In view of the increasing interest for water resources in Jordan to meet the rapidly growing demands, the need to protect the water from deterioration is becoming a must. Accordingly, Water samples from the major six springs and seven wells have been collected to study the influence of Irbid Wastewater Treatment Plant (WWTP) effluent on the groundwater quality and to classify the water of springs and wells quality according to their chemical composition and to study the quality of the springs and wells chemistry, physically and bacteriologically.

\section{MATERIALS AND METHODS}

\subsection{Location of the study area}

Wadi El-Arab Catchment Area is situated between the coordinates 208-230 E and 210-230 N (Palestine Grid) and covers an area of about $267 \mathrm{Km}^{2}$, (Figure .1).

\footnotetext{
${ }^{1}$ Al-Balqa' Applied University, Faculty of Agricultural Technology, Dept. Water Resources and Environmental Management, Al-Salt, Jordan. Rakad A. Ta'any ('Corresponding Author): e-mail: rakad.ayed@yahoo.com, Tel.: +962776361225 Fax: +96253530469 Received February10, 2013, Accepted March10, 2013
} 
The general shape of the basin is oval with the longer axis oriented SE-NW direction. The general slope of the area is from East to West. The highest elevation in Wadi El- Arab basin is about $850 \mathrm{~m}$ near Irbid City and the lowest elevation is $-170 \mathrm{~m}$ at the riverbed of Wadi AlArab dam site.

The Wadi El-Arab flows through a deep V-Shaped valley to the confluence with Wadi Zahar, the biggest tributary of Wadi El-Arab, situated at about $2 \mathrm{Km}$ upstream of dam site. The average amount of precipitation ranges from $500 \mathrm{~mm}$ over the highlands west of Irbid, to $350 \mathrm{~mm}$ in the Jordan Valley.
The average discharge of Wadi El-Arab is around 28 $\mathrm{MCM} /$ year equally distributed between flood and flows and the potential evaporation ranges from $2000 \mathrm{~mm} /$ year in the northwest, to $2400 \mathrm{~mm} /$ year in the southwest of the catchment, (Water Authority, 2009).

A dam was constructed on Wadi El-Arab catchment area in 1987, with a total capacity of about $20 \mathrm{MCM}$ to collect flood and base flow for irrigation in the Jordan Valley area. Only in the wet year 1991/1992, the dam was filled with water from its own catchment area. In the other water years, water pumped from King Abdullah Canal to the dam during the dry season.

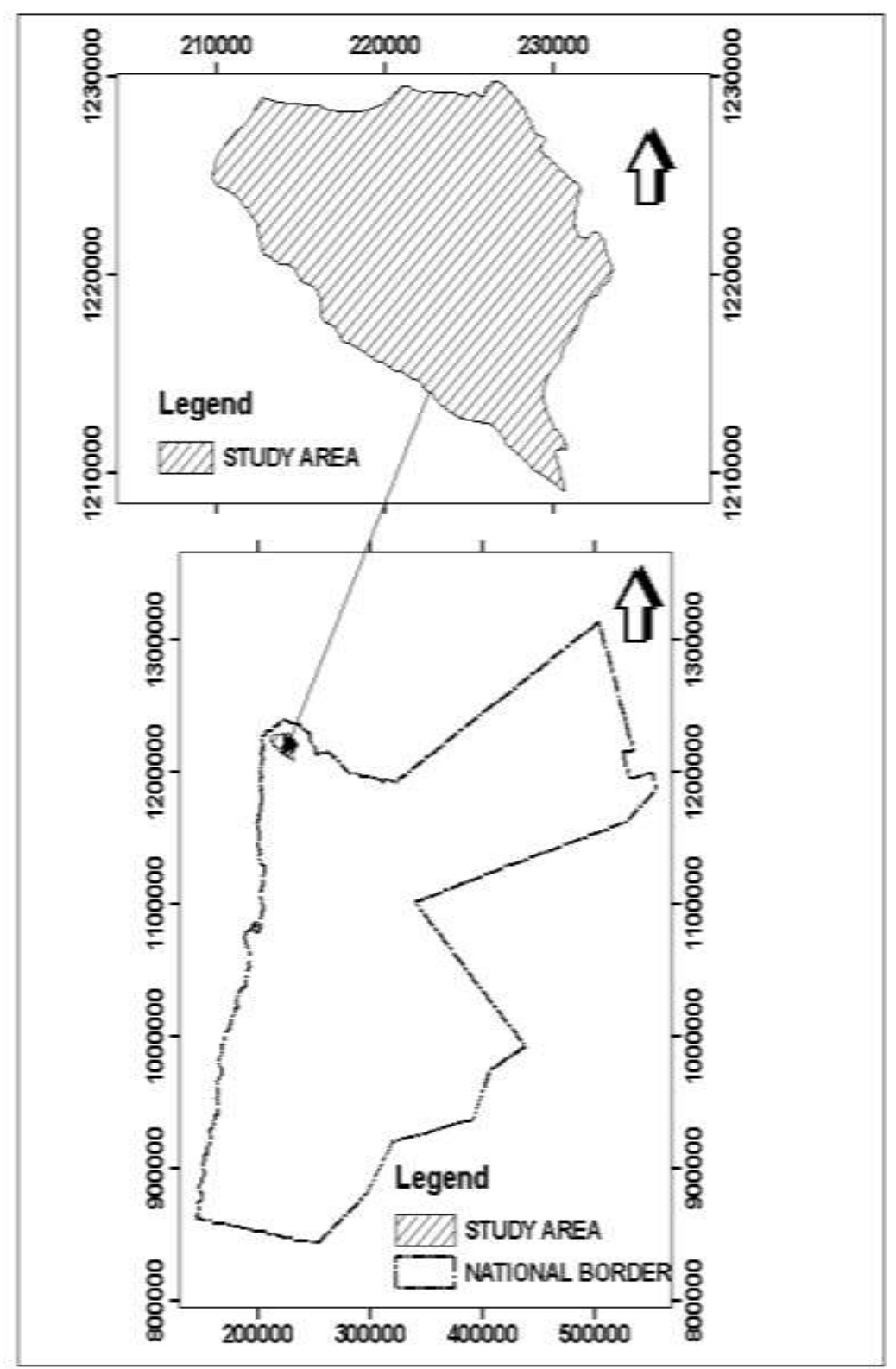

Figure 1. Location Map of Wadi El Arab Basin in Jordan 
However, the expanding of Irbid City westward into the catchment may put an increasing pressure on the quality of the water collected in the dam. The Wastewater Treatment Plant for Irbid City was constructed at the upper reaches of Wadi El- Arab. The effluent of the treatment plant is piped to bypass the dam, and so flood waters still enter the treatment plant and wash its contents and wastes along Wadi El-Arab into the dam reservoir, which negatively affecting its water quality.

\subsection{Drainage and Topography}

Wadi El-Arab is situated on the East Bank of the Jordan Rift Valley about $10 \mathrm{Km}$ south of Lake Tiberius, occupying an area of $267 \mathrm{Km}^{2}$ (Figure .2). Wadi ElArab originates near Irbid and runs westward to pour into the Jordan River.

The highest spot is $850 \mathrm{~m}$ south of Irbid, and lowest spot is $200 \mathrm{~m}$ near North Shauna. The deep V-shaped is formed in the mid upstream parts, where as the Wadi meanders in wide-open valley in the downstream river terraces, were formed $100 \mathrm{~m}$ to $150 \mathrm{~m}$ wide, and under the cliffs cut by side erosion on both banks. Wadi Zahar, a big tributary of the Wadi El- Arab, forms rather a straight valley trending from south to north. The confluence to the Wadi El-Arab is located about $1.7 \mathrm{Km}$ upstream from the dam site, (Ghrefat, 1999).

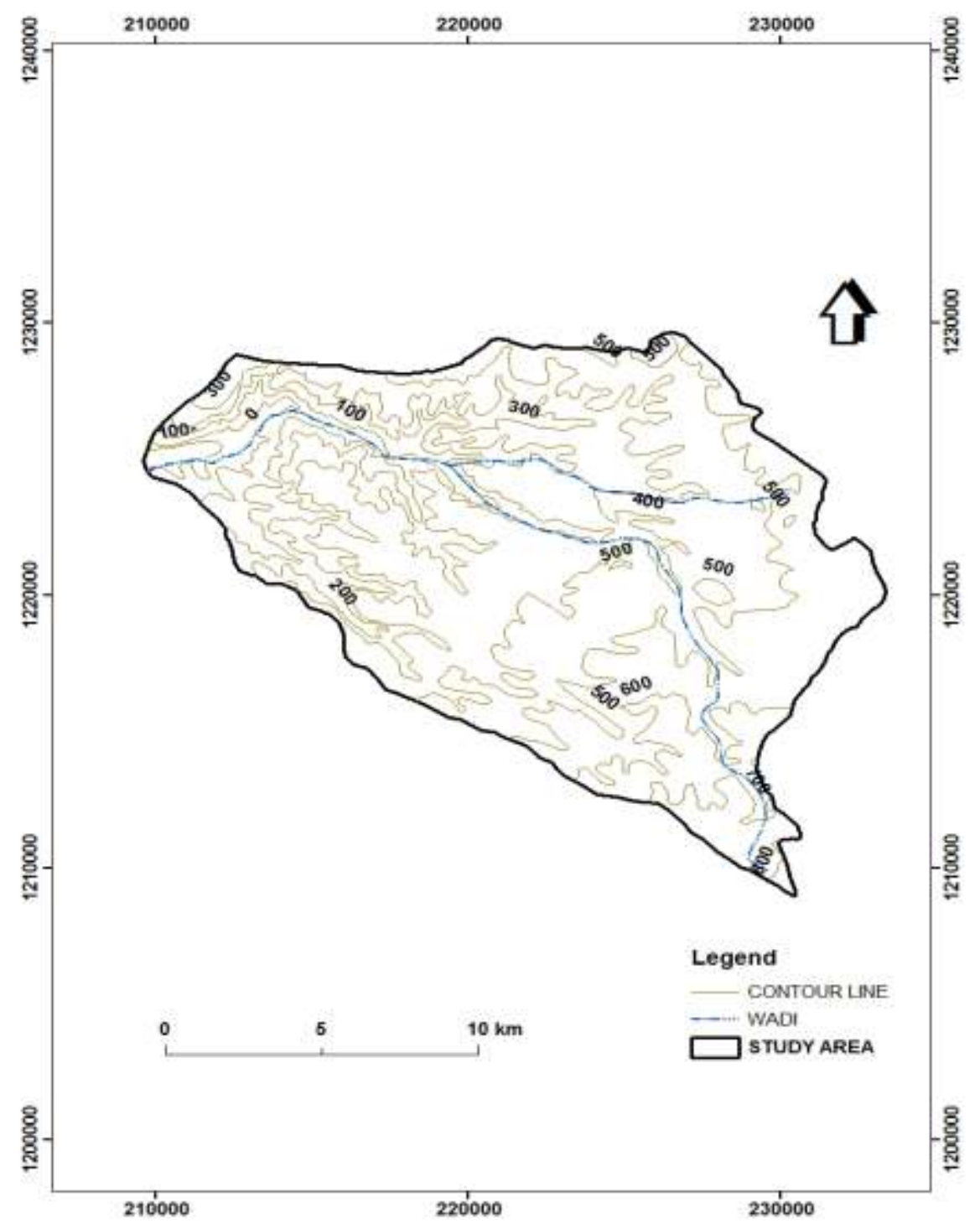

Figure 2. Topographic Map of Wadi El-Arab Basin 


\subsection{Hydrogeology}

Wadi El-Arab basin is situated adjacent to the Jordan River Valley. The geological structure and tectonic features in the Wadi El Arab basin is highly related to the structure of Jordan Rift Valley. The geological successions in Wadi El-Arab hydrogologically subdivided into lothostratigraphic units, which form aquifers and aquicludes.

Amman Wadi Es - Sir Formation $\left(\mathrm{B}_{2} / \mathrm{A}_{7}\right)$ is the main aquifer system in Wadi El-Arab Basin. The groundwater of this basin is described as unconfined aquifer system in the basin. There are six wells in Wadi El-Arab, taping the aquifer at various depths, in addition to five springs issue from the same aquifer. According to (Salem, $1999)$, the transmissivity of the $\left(B_{2} / A_{7}\right)$ aquifer ranges from $9 \mathrm{~m}^{2} /$ day to more than $900 \mathrm{~m}^{2} /$ day. The storage coefficient of this aquifer in the confined condition vary from $10^{-3}$ to $10^{-5}$, while the specific capacity vary from less than $0.01 \mathrm{~L} / \mathrm{s} / \mathrm{m}$ to more than $50 \mathrm{~L} / \mathrm{s} / \mathrm{m}$. The permeability ranges from 0.01 to more than $100 \mathrm{~m} /$ day, (MWI, 2009).

The aquifer system receives two types of recharge: direct and indirect. The direct recharge occurs as rainfall entering into the aquifer, while the indirect recharge takes place along wadis due to flood flows or via the overlying Quaternary Deposits. Tables (1 and 2) show the main wells and springs exist in the basin. Aquifers and aquitards as well as the soil cover make direct recharge as infiltration from the rainfall limited to the outcrops of the aquifer. The $\mathrm{B}_{2} / \mathrm{A}_{7}$ crops out in the eastern and southern border of the Basin, where direct recharge occurs (Fig 3).

The main mechanism of groundwater movement is by fracture flow. Regional groundwater movement within the Amman Wadi Es-Sir (B2/A7) aquifer mostly follows the regional dip to the west. Groundwater movement generally depends on the hydraulic conductivity and the hydraulic gradient. Groundwater elevations are highest in the extremely north of the catchment area and range from more than $800 \mathrm{~m}$ above the mean sea level (a.m.s.l) to less than minus $100 \mathrm{~m}$. Figure 4, shows the flow-net map of the Upper Aquifer System (B2/A7) in the basin. This figure shows that the flow direction is mainly from east to west.

\subsection{Hydrology}

\subsubsection{Determination of the Average Areal Rainfall}

Wadi El Arab basin has a predominantly Mediterranean type climate, characterized by hot dry summers and cool to cold rainy winters. As in most semi-arid areas, temperatures exhibit large seasonal and diurnal variations, with absolute daily temperatures ranging from a maximum of around $37{ }^{\circ} \mathrm{C}$ in August to $-3{ }^{\circ} \mathrm{C}$ in January, (JMD, 2010). Rainfall generally begins in October and lasts in May, the remaining months of the year are dry. Isohyetal method was used to determine the mean rainfall precipitated over the basin. The annual precipitation decreases across the catchment area from the northwest to southeast from over $450 \mathrm{~mm}$ to less than $300 \mathrm{~mm}$ (Fig 5). In summer, the seasonal low pressure over the eastern Mediterranean area and Arabian Gulf creates westerly to northwesterly winds over Jordan and is associated with high temperatures and no rainfall during the months June to September. As the pressure system changes in autumn and the seasonal trough migrates to the south east, the development of Mediterranean depressions brings in continental air from the Asiatic Steppes and warmer moist air from the Mediterranean Sea, causing falling temperatures and the onset of winter frontal rains (Oct-Nov to April-May). Towards the end of winter season, thunderstorms are often associated with unstable air at higher altitudes.

Table 1. The locations and depths of the studied wells*

\begin{tabular}{lccccc}
\hline \multirow{2}{*}{ Well Name } & \multicolumn{2}{c}{ Palestine Grid Coordinates } & Altitude & Aquifer & \multicolumn{2}{c}{ Total Depth } \\
\cline { 2 - 3 } & $\mathbf{E}$ & $\mathbf{N}$ & $\mathbf{m})$ & $\begin{array}{c}\text { type } \\
(\mathbf{m})\end{array}$ \\
\hline Wadi Al-Arab well No.1 & 211.947 & 1224.19 & 11.00 & $\mathrm{~B}_{2} / \mathrm{A}_{7}$ & 703 \\
\hline Wadi Al-Arab well No.2 & 212.067 & 1225.150 & 17.00 & $\mathrm{~B}_{2} / \mathrm{A}_{7}$ & 407 \\
\hline Wadi Al-Arab well No.3 & 212.650 & 1225.600 & -20.00 & $\mathrm{~B}_{2} / \mathrm{A}_{7}$ & 257 \\
\hline Wadi Al-Arab well No.4 & 213.300 & 1226.500 & 26.80 & $\mathrm{~B}_{2} / \mathrm{A}_{7}$ & 750 \\
\hline Wadi Al-Arab well No.5 & 212.850 & 1222.550 & 50.00 & $\mathrm{~B}_{2} / \mathrm{A}_{7}$ & 375 \\
\hline Wadi Al-Arab well No.6 & 213.032 & 1222.460 & 80.00 & $\mathrm{~B}_{2} / \mathrm{A}_{7}$ & 303 \\
\hline Kafr Asad Exploration well & 220.200 & 1221.130 & 337.00 & $\mathrm{~B}_{2} / \mathrm{A}_{7}$ & 341 \\
\hline
\end{tabular}

*Source: MWI, 2011 
Table 2. The locations and type of aquifer types of the studied springs*

\begin{tabular}{|c|c|c|c|c|c|}
\hline & \multirow{2}{*}{ Spring Nan- } & \multicolumn{2}{|c|}{ Palestine Grid Coordinates } & \multirow{2}{*}{$\begin{array}{c}\text { Altitude } \\
\text { (m) }\end{array}$} & \multirow{2}{*}{ Aquifer type } \\
\hline & & $\mathbf{E}$ & $\mathbf{N}$ & & \\
\hline Barruqa & & 218.6 & 227.6 & 300 & $\mathrm{~B}_{2} / \mathrm{A}_{7}$ \\
\hline Um Jurn & & 213.8 & 226.2 & 100 & $\mathrm{~B}_{2} / \mathrm{A}_{7}$ \\
\hline Rood El Tarqaba & & 213.8 & 226.2 & 78 & $\mathrm{~B}_{2} / \mathrm{A}_{7}$ \\
\hline Tell Zeraa' & & 211.9 & 225.1 & -20 & $\mathrm{~B}_{2} / \mathrm{A}_{7}$ \\
\hline Um Qeis & & 213.5 & 228.2 & 220 & $\mathrm{~B}_{3}$ \\
\hline Zahar & & 213.05 & 222.5 & 75 & $\mathrm{~B}_{2} / \mathrm{A}_{7}$ \\
\hline
\end{tabular}

* Source: Ministry of Water and Irrigation, (MWI, 2011).

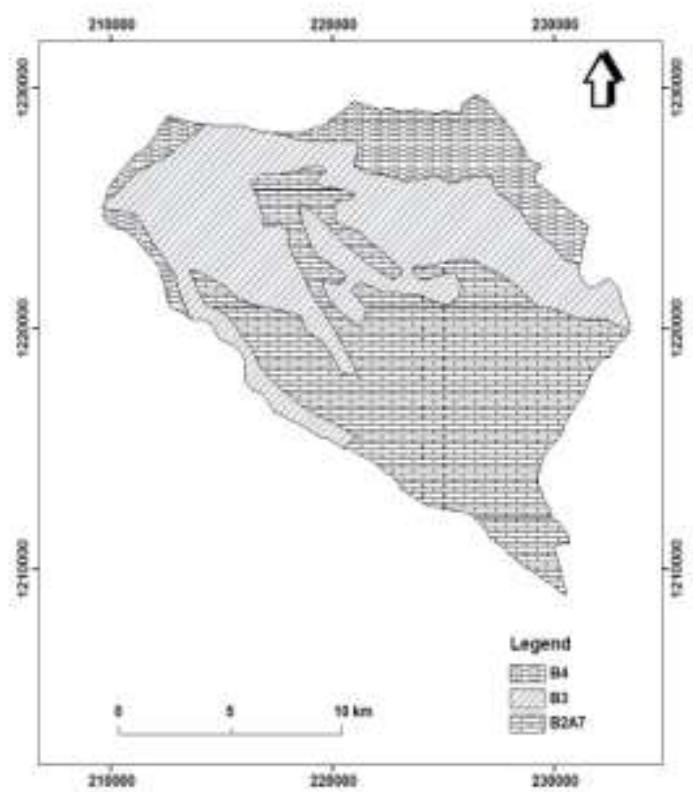

Figure 3. Geologic Map of the Basin

\subsubsection{Determination of Runoff}

The determination of flows was done by applying the United States soil conservation service (SCS) (curve number) approach to the available rainfall data. This method takes in consideration the antecedent moisture conditions (AMC), the initial abstraction of rainfall, and the land use. The general equation relating the accumulated runoff to accumulated rainfall is:

$$
P_{e}=\frac{\left(P-I_{a}\right)^{2}}{P-I_{a}+S}
$$

\section{Where:}

$P_{e:}$ the depth of excess precipitation depth or direct runoff in inches

P: the depth of precipitation in inches

$\mathrm{I}_{\mathrm{a}}$; The initial abstraction before ponding in inches

$S$ : the potential maximum retention depth in inches

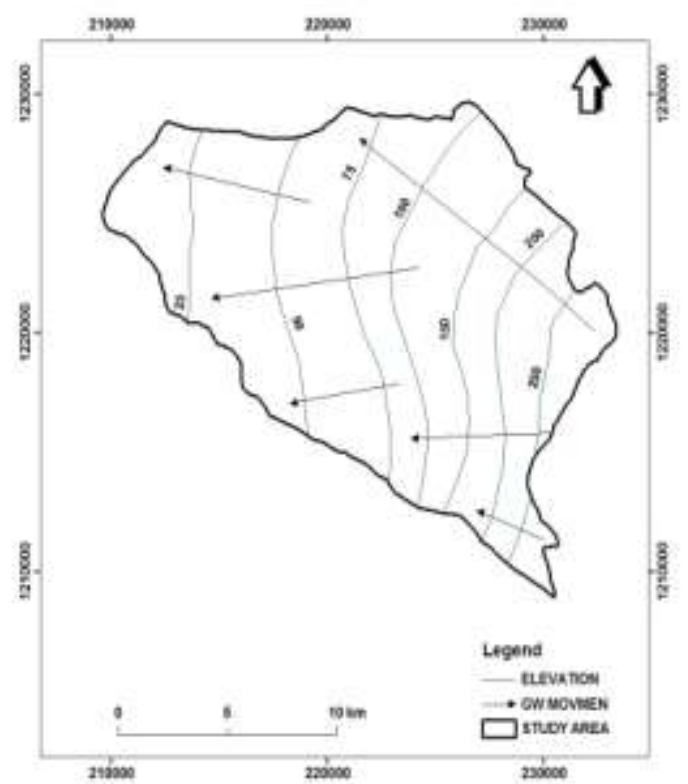

Figure 4. Flow-net map of the Basin

By studying the results of many small experimental watersheds, an empirical relation was developed as:

$$
I_{a}=0.2 S
$$

On this basis

$$
Q=\frac{(P-0.2 S)^{2}}{P+0.8 S}
$$

The curve number and $\mathrm{S}$ are related by:

$S=\frac{1000}{C N}-10$

The curve number $(\mathrm{CN})$ is defined in terms of the watershed land cover and hydrologic soil group types, (SCS, 1985). This number can be obtained from a graphical solution. A higher number means that great amount of direct runoff is expected from a storm. 


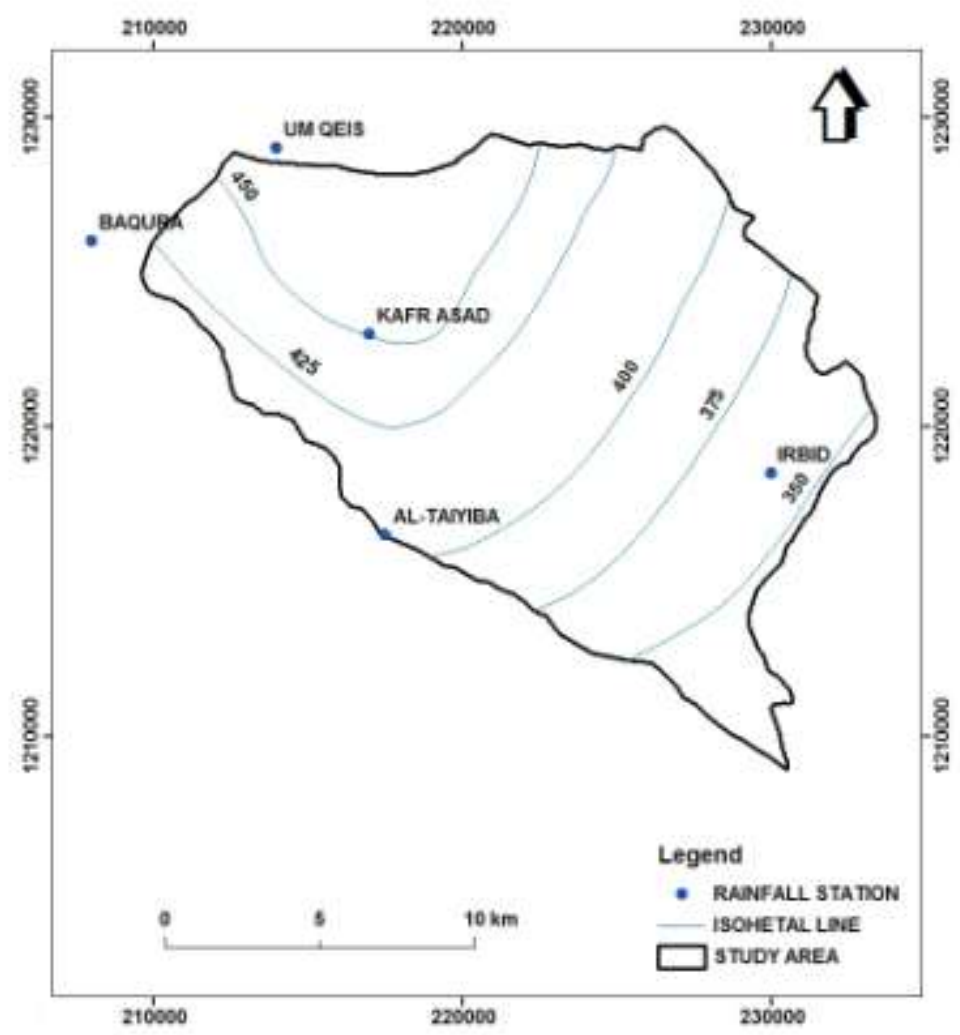

Figure 5. Isohyetal Map of Wadi El Arab Basin

\subsubsection{Chemical analyses of water samples:}

Water samples from six springs and seven wells have been collected and analyzed in Water Authority of Jordan (WAJ) central laboratories. to study the influence of Irbid Wastewater Treatment Plant (WWTP) effluent on the groundwater quality and to classify the water of springs and wells quality according to their chemical composition furthermore, to study the quality of the springs and wells chemistry, physically and bacteriologically. For $\mathrm{Ca}^{2+}, \mathrm{Mg}^{2+}, \mathrm{Na}^{+}, \mathrm{K}^{+}$Varian AAS has been used and for $\mathrm{HCO}_{3}{ }^{-}$and $\mathrm{Cl}^{-}$, titration method is used while for $\mathrm{SO}_{4}{ }^{2-}$ and $\mathrm{NO}_{3}{ }^{-} \mathrm{UV}$ spectrophotometer is used. The total hardness (TH) in $\mathrm{mg} / \mathrm{l}$ was calculated as follows:

$T H=2.5 C a+4.1 M g, \quad(T o d d, \quad 1980)$ and the concentrations of $\mathrm{Ca}$ and $\mathrm{Mg}$ are in $\mathrm{mg} / \mathrm{l}$.

The accuracy of the analysis has been checked using the ionic balance according to Appelo and Postma (1996). The balance was found to be less than 5\%, which indicates that the analysis is satisfactorily accurate.

\section{RESULTS AND DISCUSSIONS}

Jordan economic growth, industrialization, and urbanization - accompanied by inadequate infrastructure investment and management capacity - have all contributed to widespread problems of water scarcity and water pollution throughout the country. Scarcity of water resources and their pollution are considered gravest environmental challenge facing Jordan, due to arid to semi-arid climate, high population growth and depletion of water resources. These issues will increase the gap between water demand and supply. Besides the stress on the water resources, which are considered to cover the demand of population and development of agricultural activities.

\subsection{Hydrological characteristics:}

Runoff estimation in un-gauged catchment is a challenge for the hydrological engineers and planners. For any hydrological study on an un-gauged watershed, a methodology has to be appropriately selected for the determination of runoff at its outlet. Several methods have been used to estimate the runoff from a watershed. 
In this research The US Department of Agriculture, Natural Resources US Soil Conservation Service Curve Number (SCS, 1985) was used to calculate the runoff in Wadi El-Arab catchment. The Curve Number method (SCS-CN) of estimating rainfall excess from rainfall depth is widely used in applied hydrology. Based on field observation, geologic conditions, soil type, vegetation cover and the topography of the study area, the curve number 70 is found to represent the normal condition for Wadi El- Arab Catchment Area. Then formulae discussed in section 2.4.2 were used to estimate the runoff from each effective storm for the whole catchment.

Estimation of evaporation rate and total evaporation over a water year is of great importance in the water management problems, especially in arid region. The potential evapotranspiration was computed by applying Penman Formula, (Penman, 1963) as mentioned previously, which appears to be the most suitable and had been widely used with satisfactory results in various parts of the world, particularly in arid and semi-arid areas as the case in Wadi El Arab catchment area. The potential evapotranspiration (ET) was computed for the period from 1997 to 2009 .The average annual evapotranspiration (ET) according to Penman was found to be $154.84 \mathrm{MCM}, 109.24 \mathrm{MCM}$ and $56.84 \mathrm{MCM}$ in the wet, normal and dry conditions respectively. The rate of evaporation ranges between 71.2 percent in the wet year and 94.20 percent in the extremely dry water year.

The infiltration amounts were estimated according to the following equation:

$\Delta=\mathrm{P}-(\mathrm{E}+\mathrm{R}) \pm \mathrm{I}_{\mathrm{a}}$

(Fetter, 1988).

The direct infiltration was calculated annually by subtracting the sum of daily runoff and the sum of daily evapotranspiration (E) and initial abstraction $\left(I_{a}\right)$ from the annual rainfall.

The average annual recharge to the upper aquifer of Wadi El Arab catchment was calculated to be about 7.01 MCM. The results of the water balance calculations for the whole catchment are presented in Table (3). Also the maximum recharge is $16.31 \mathrm{MCM}$ and the minimum recharge is $2.11 \mathrm{MCM}$. The infiltration rate ranged between 3.5 percent and 7.5 percent.

\subsection{Water Quality}

The geochemical properties of groundwater generally depend on those of the recharge water (atmospheric precipitation, inland surface water, seawater) and on subsurface geochemical process. The quality of any type of water reflects its potential use for domestic, industrial and irrigational purposes, (Al Nasir and Batarseh, 2009). Water quality assurance is one of the most important perquisites for water use allocation. The chemical and biological compositions of water are derived from many sources in the investigated area are discussed below.

\subsubsection{Water Quality for Domestic Water}

The quality of water resources depends on the intended use such as domestic, irrigation and industrial uses. Several parameters were calculated to determine the suitability of the springs and wells water quality for domestic and irrigation purposes.

The suitability of the spring water for domestic purposes was determined by comparing the concentration of constituents with the World Health Organization (WHO, 1993) guidelines and Jordanian standards for drinking water, (JS, 1997). All springs and wells in the study area are fit with WHO guidelines and Jordanian standards and can be used for domestic purposes. The long - term average electrical conductivity (EC) values range between $625 \mu \mathrm{s} / \mathrm{cm}$ at Wadi Zahar spring and $945.6 \mu \mathrm{s} / \mathrm{cm}$ at Um Jurn spring. While EC- values range between $570 \mu \mathrm{s} / \mathrm{cm}$ at Wadi ElArab Well (5) and $1500 \mu \mathrm{s} / \mathrm{cm}$ at Kufr Asad Exploration well. In addition, the long-term average nitrate concentrations range between $4 \mathrm{mg} / \mathrm{l}$ at Tell Zeraa' spring and $32.3 \mathrm{mg} / \mathrm{l}$ at Um Jurn spring. While nitrate concentrations range between $1.4 \mathrm{mg} / \mathrm{l}$ at Wadi El-Arab Wells (2 and 3) and 15.9 at Kufr Asad exploration well, Tables (4 and 5) and Figs (6,7,8 and 9).

The classification of water hardness was achieved based on Sawyer and McCarty, (1967) classifications as shown in table (6). Generally, all springs water and wells water are classified as very hard water. This is due to the nature of limestone aquifer. Tables (7 and 8) represent the classification of the wells water based on their hardness.

Table 3. Calculated water balance for Wadi El Arab catchment area

\begin{tabular}{cccccccc}
\hline $\begin{array}{c}\text { Water } \\
\text { Year }\end{array}$ & $\begin{array}{c}\text { Rainfall } \\
\text { MCM* }\end{array}$ & $\begin{array}{c}\text { Runoff } \\
\text { MCM }\end{array}$ & $\begin{array}{c}\text { Evaporation } \\
\text { MCM }\end{array}$ & $\begin{array}{c}\text { Infiltration } \\
\text { MCM }\end{array}$ & $\begin{array}{c}\text { Runoff } \\
\text { rate\% }\end{array}$ & $\begin{array}{c}\text { Evaporation } \\
\text { rate\% }\end{array}$ & $\begin{array}{c}\text { Infiltration } \\
\text { rate \% }\end{array}$ \\
\hline Wet (1997/1998) & 217.47 & 46.32 & 154.84 & 16.31 & 21.3 & 71.2 & 7.5 \\
\hline Normal (1996/1997) & 132.25 & 16.00 & 109.24 & 7.01 & 12.1 & 82.6 & 5.3 \\
\hline Dry $(2004 / 2005)$ & 60.34 & 1.39 & 56.84 & 2.11 & 2.3 & 94.2 & 3.5 \\
\hline
\end{tabular}

* MCM (Million cubic meter 
Table 4. Average Electrical Conductivity and Nitrate Concentrations for the Major Springs

\begin{tabular}{ccccccc}
\hline Parameters & Um Jurn & Um Qeis & Barruqa & Tarbaqa & $\begin{array}{r}\text { Tell } \\
\text { Zeraa }\end{array}$ & Zahar \\
\hline $\mathrm{EC}(\mu \mathrm{s} / \mathrm{cm})$ & 945.6 & 834.2 & 642.9 & 914.6 & 806.1 & 625 \\
\hline $\mathrm{NO}_{3}^{-}(\mathrm{mg} / \mathrm{l})$ & 11.4 & 32.3 & 23.4 & 8.1 & 4 & 18.7 \\
\hline
\end{tabular}

Table 5. Average Electrical Conductivity and Nitrate Concentrations for the Major Wells

\begin{tabular}{cccccccc}
\hline \multirow{2}{*}{ Parameters } & Kufr Asad & $\begin{array}{c}\text { W. El- } \\
\text { Arab.1 }\end{array}$ & $\begin{array}{c}\text { W. El- } \\
\text { Arab.2 }\end{array}$ & $\begin{array}{c}\text { W. El- } \\
\text { Arab.3 }\end{array}$ & $\begin{array}{c}\text { W. El- } \\
\text { Arab.4 }\end{array}$ & $\begin{array}{c}\text { W. El- } \\
\text { Arab.5 }\end{array}$ & $\begin{array}{c}\text { W. El- } \\
\text { Arab.6 }\end{array}$ \\
\hline $\mathrm{EC}(\mu \mathrm{s} / \mathrm{cm})$ & 1308.5 & 869.7 & 830.1 & 842.6 & 931.2 & 770.3 & 795.0 \\
\hline $\mathrm{NO}_{3}{ }^{-}(\mathrm{mg} / \mathrm{l})$ & 15.9 & 1.5 & 1.4 & 1.4 & 1.6 & 11.7 & 14.1 \\
\hline
\end{tabular}

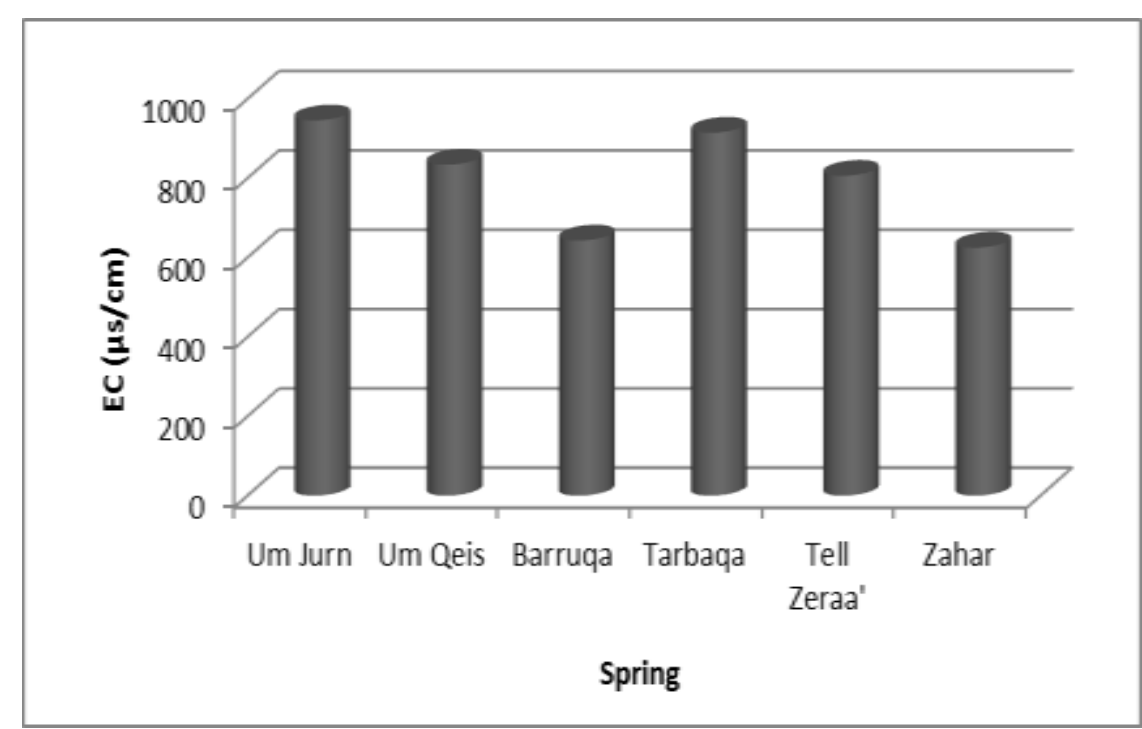

Figure 6. Fluctuation of Electrical Conductivity for the Major Springs

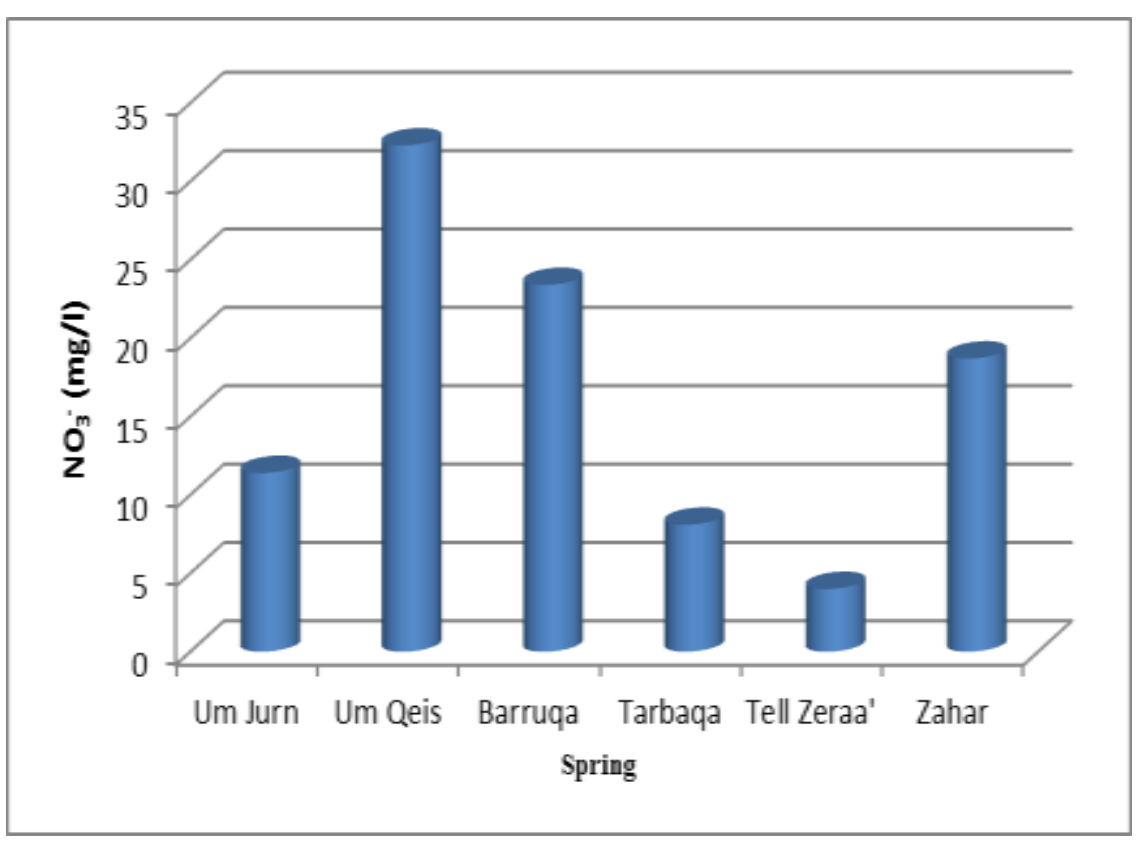

Figure 7.Fluctuation of Nitrate Concentrations for the Major Springs 


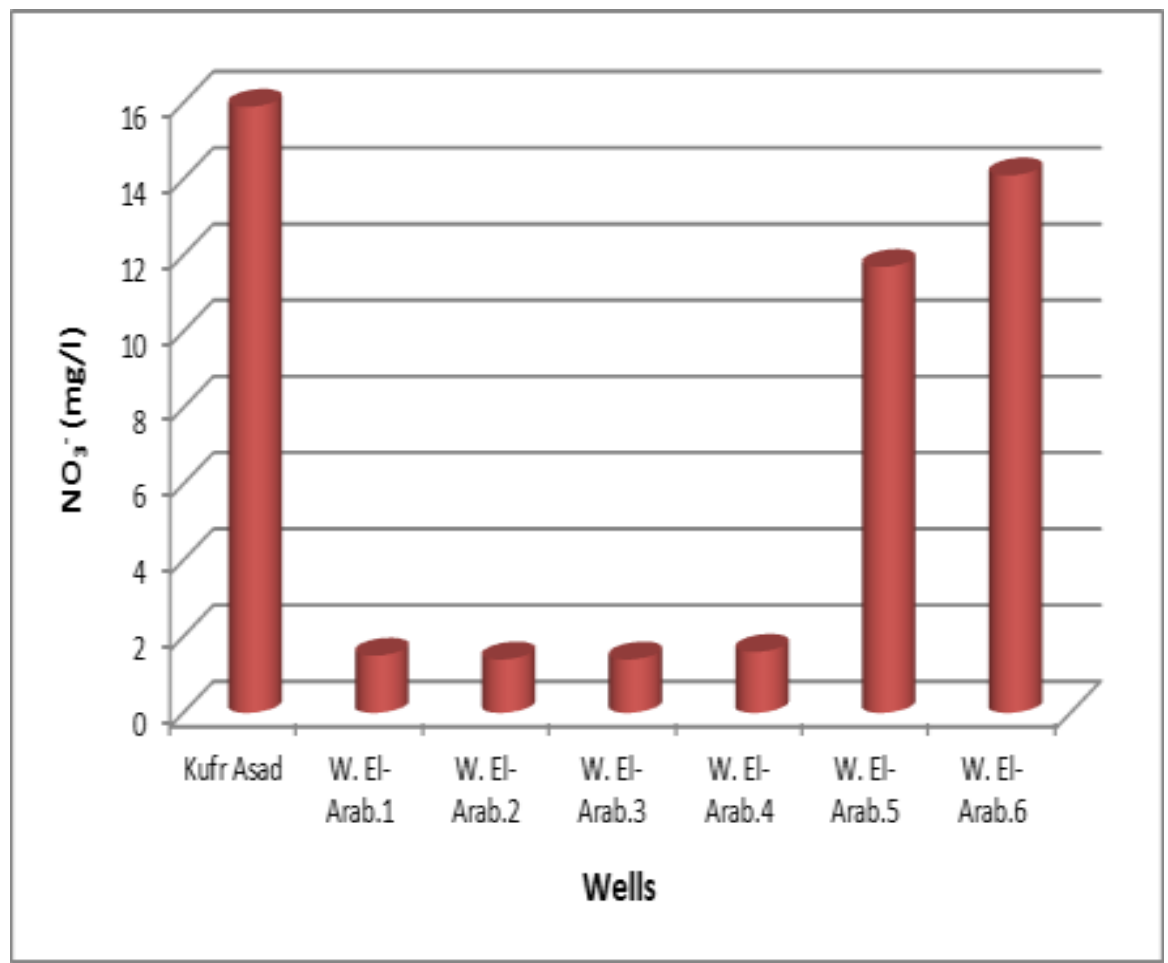

Figure 8. Fluctuation of Nitrate Concentrations for the Major Wells

Table 6. Classification of water based on hardness (Sawyer and McCarty, 1967)

\begin{tabular}{ll}
\hline Hardness as $\mathrm{CaCO}_{\mathbf{3}}(\mathbf{m g} / \mathbf{l})$ & Water class \\
\hline $0-75$ & Soft \\
\hline $75-150$ & Moderately hard \\
\hline $150-300$ & Hard \\
\hline$>300$ & Very hard \\
\hline
\end{tabular}

Table 7. Classification of springs' water based on hardness

\begin{tabular}{lcl}
\hline Spring name & Hardness as $\mathbf{C a C O}_{\mathbf{3}} \mathbf{( m g / l )}$ & Water class \\
\hline Barruqa Spring & 426.5 & Very hard \\
\hline Um Qeis Spring & 385.8 & Very hard \\
\hline Um Jurn Spring & 615.8 & Very hard \\
\hline Rood El Tarqaba Spring & 575.7 & Very hard \\
\hline Tell Zeraa' Spring & 549.4 & Very hard \\
\hline Wadi Zahar Spring & 442.4 & Very hard \\
\hline
\end{tabular}

Table 8. Classification of wells' water based on hardness

\begin{tabular}{lcl}
\hline Well name & Hardness as $\mathbf{C a C O}_{\mathbf{3}}(\mathbf{m g} / \mathbf{l})$ & Water class \\
\hline Kufr Asad Exp.well & 385.8 & Very hard \\
\hline Wadi El-Arab well (1) & 385.8 & Very hard \\
\hline Wadi El-Arab well (2) & 385.8 & Very hard \\
\hline Wadi El-Arab well (3) & 385.8 & Very hard \\
\hline Wadi El-Arab well (4) & 385.8 & Very hard \\
\hline Wadi El-Arab well (5) & 385.8 & Very hard \\
\hline Wadi El-Arab well (6) & 385.8 & Very hard \\
\hline
\end{tabular}




\subsubsection{Irrigation Water}

The suitability of water for irrigation is affected by its mineral constituents and their impacts on both plant and soil (Todd, 1980). The limiting factors concerning water quality for irrigation purposes are the salinity hazard and Sodium Adsorption Ratio (SAR), The SAR has a direct relation to the adsorption of sodium by soil and plants. The SAR is defined as:

$$
S A R=\frac{N a}{\sqrt{\frac{(C a+M g)}{2}}}
$$

Where;

$\mathrm{Na}^{+}:$meq/1; $\mathrm{Ca}^{+2}:$ meq/l; $\mathrm{Mg}^{+2}$ meq/l

The classification of springs and wells water based on Salinity and SAR are listed in tables (7) and (8) respectively.

In respect of Tables (7) and (8) it can be observed that, the water of each springs, Barruqa and Wadi Zahar, in addition to the water of Wadi El-Arab Well (6) are classified as medium salinity hazard $\left(\mathrm{C}_{2}\right)$ and low sodium hazard $\left(\mathrm{S}_{1}\right)$, and the water of other springs and wells are classified as high salinity $\left(\mathrm{C}_{3}\right)$ and low sodium hazard $\left(S_{1}\right)$.

\subsubsection{Bacteriological Analyses}

The bacteriological analysis is important for detecting biological pollution of groundwater. Most pathogenic bacteria found in water are indigenous to the intestinal tract of animals and humans, but isolating them from natural water is difficult in the laboratory. Because bacteria of the coliform group are relatively easy to isolate and identify, standard tests to determine their presence or absence in a water sample are taken as a direct indication of the safety of the water for drinking purposes.

Coliform test results are reported as the most probable number (MPN) of coliform group organisms in a given volume of water. By analysis of a number of separate portions of a water sample, the MPN is computed from probability tables for this purpose, (Todd, 1980). The presence of total coliform is an index of bacteriological pollution in water samples

The collected wells water samples were analyzed in the laboratories of north water directorate, (Water Authority-Irbid). The results of bacteriological tests are listed in Table (9). According to the World Health Organization and Jordan standards, the water is considered suitable for drinking when the most probable number (MPN) for total coliform does not exceed 2.2 MPN per $100 \mathrm{ml}$, and the faecal coliform bacteria does not exist in the same $100 \mathrm{ml}$. According to the results shown in Table 9, the whole wells exist in Wadi El Arab catchment are suitable for drinking.

Table 7. Classification of springs water use for irrigation based on salinity and (SAR)

\begin{tabular}{lccl}
\hline Spring name & $\mathbf{E C}(\boldsymbol{\mu s} / \mathbf{c m})$ & SAR & Class \\
\hline Barruqa Spring & 642.9 & 0.40 & $\mathrm{C}_{2}-\mathrm{S}_{1}$ \\
\hline Um Qeis Spring & 834.2 & 0.92 & $\mathrm{C}_{3}-\mathrm{S}_{1}$ \\
\hline Um Jurn Spring & 945.6 & 0.90 & $\mathrm{C}_{3}-\mathrm{S}_{1}$ \\
\hline Rood El Tarqaba Spring & 914.6 & 0.80 & $\mathrm{C}_{3}-\mathrm{S}_{1}$ \\
\hline Tell Zeraa' Spring & 806.1 & 0.47 & $\mathrm{C}_{3}-\mathrm{S}_{1}$ \\
\hline Wadi Zahar Spring & 625.0 & 0.44 & $\mathrm{C}_{2}-\mathrm{S}_{1}$ \\
\hline
\end{tabular}

Table 8. Classification of wells water use for irrigation based on salinity and (SAR)

\begin{tabular}{lccl}
\hline Wells name & EC $(\boldsymbol{\mu} \mathbf{s} / \mathbf{c m})$ & SAR & Class \\
\hline Kufr Asad Exploration well & 1308.5 & 1.19 & $\mathrm{C}_{3}-\mathrm{S}_{1}$ \\
\hline Wadi El-Arab well (1) & 869.7 & 0.59 & $\mathrm{C}_{3}-\mathrm{S}_{1}$ \\
\hline Wadi El-Arab well (2) & 830.0 & 0.48 & $\mathrm{C}_{3}-\mathrm{S}_{1}$ \\
\hline Wadi El-Arab well (3) & 842.6 & 0.49 & $\mathrm{C}_{3}-\mathrm{S}_{1}$ \\
\hline Wadi El-Arab well (4) & 931.2 & 0.71 & $\mathrm{C}_{3}-\mathrm{S}_{1}$ \\
\hline Wadi El-Arab well (5) & 770.3 & 0.44 & $\mathrm{C}_{3}-\mathrm{S}_{1}$ \\
\hline Wadi El-Arab well (6) & 508.8 & 0.42 & $\mathrm{C}_{2}-\mathrm{S}_{1}$ \\
\hline
\end{tabular}


Table 9. Bacteriological Analyses for the collected wells water samples

\begin{tabular}{lcc}
\hline \multicolumn{1}{c}{ Wells name } & Total Coliform MPN/100ml & Faecal Coliform MPN/l 100ml \\
\hline Kufr Asad Exploration well & $<2.2$ & n.d* \\
\hline Wadi El-Arab well (1) & $<2.2$ & n.d \\
\hline Wadi El-Arab well (2) & $<2.2$ & n.d \\
\hline Wadi El-Arab well (3) & $<2.2$ & n.d \\
\hline Wadi El-Arab well (4) & $<2.2$ & n.d \\
\hline Wadi El-Arab well (5) & $<2.2$ & n.d \\
\hline Wadi El-Arab well (6) & $<2.2$ & n.d \\
\hline
\end{tabular}

*n.d: not detected

\section{CONCLUSION}

-The annual precipitation decreases across Wadi ElArab catchment area from the northwest to southeast from over $450 \mathrm{~mm}$ to less than $300 \mathrm{~mm}$.

-The rate of evaporation ranges between 71.2 percent in the wet year and 94.20 percent in the extremely dry water year.

-The infiltration rate ranges between 3.5 percent and 7.5 percent.

-All springs and wells in the study area are fit with WHO guidelines and Jordanian standards and can be used for domestic purposes.

-The long - term average electrical conductivity (EC) values ranged between $625 \mu \mathrm{s} / \mathrm{cm}$ at Wadi Zahar spring and $945.6 \mu \mathrm{s} / \mathrm{cm}$ at Um Jurn spring. While EC- values ranged between $570 \mu \mathrm{s} / \mathrm{cm}$ at Wadi ElArab Well (5) and $1500 \mu \mathrm{s} / \mathrm{cm}$ at Kufr Asad Exploration well.

-The long - term average nitrate concentrations ranged between $4 \mathrm{mg} / \mathrm{l}$ at Tell Zeraa' spring and $32.3 \mathrm{mg} / \mathrm{l}$ at Um Jurn spring. While nitrate concentrations ranged between $1.4 \mathrm{mg} / \mathrm{l}$ at Wadi El-Arab Wells (2 and 3) and 15.9 at Kufr Asad exploration well.

-The springs and wells water were classified into two groups: Barruqa, Wadi Zahar Springs and Wadi ElArab Well (6) are classified as $\mathrm{C}_{2}-\mathrm{S}_{1}$ while other springs and wells are classified as $\mathrm{C}_{3}-\mathrm{S}_{1}$ According to the U.S Salinity Laboratory Classification, Richard, (1954).

-The bacteriological analyses indicate that the studied wells are non-polluted by total coliform and faecal coliform.

\section{REFERENCES}

Al Nasir, F, Batarseh M, 2009. Agricultural reuse of reclaimed water and uptake of organic compounds: Pilot study at Mu'tah University wastewater treatment plant, Jordan. Chemosphere, 72,(2008), 1203-1214.

Appelo, C.A.J., and Postma, D. 1996. Geochemistry, Groundwater and Pollution. Published by A.A. Balkema, Brookfield, VT.
Fetter CW, 1988. Applied Hydrogeology, 2nd edition. Merrill publishing Company, London, p 592.

Ghrefat H. 1999. Hydrochemical and geochemical study of Wadi Al-Arab Dam and Wells: with special regard to the environmental pollution (MSc thesis). Yarmouk University.

Haddadin, M. 2005. Water resources in Jordan, evolving policies for development, the environment, and Conflict Resolution. Washington DC, USA.

JMD (Jordan Meteorological Department), 2010. Annual report, Ministry of Transport. Amman, Jordan.

JS (Jordanian standards), 1997. Jordanian Drinking Water Standards JS 286/1997.

MWI (Ministry of Water and Irrigation), 2009. Open files. Amman, Jordan.

MWI (Ministry of Water and Irrigation), 2011. Water sector investment program in (1997-2011). Amman, Jordan.

Penman, H. L., 1963. Natural evaporation from open water, bare soil and grass. Royal Soc. London Proc., Ser. A, V. 193, No. 1032, pp. 120-145.

U.S Salinity Laboratory, 1954. Diagnosis and improvement of saline and alkali soils. U.S Department of Agriculture, Handbook No. 60, p 160.

Salem, H.S., 1999. Determination of fluid transmissivity and electric transverse resistance for shallow aquifers and deep reservoirs from surface and well-log electric measurements. Hydrology and Earth System Sciences 3 (3), 421-427.

Sawyer, C.N and McCarty, P.L, 1967. Chemistry and Sanitary engineers, second edition, McGraw-Hill, New York.

SCS (U.S.A Soil Conservation Service), 1985. National Engineering Handbook Section-4, Hydrology, Soil Conservation Service, USDA.

Ta'any, R. and Al-Zu'bi, Y. 2007. Rainfall network optimization in Jordan as an example of Mediterranean Sea region. Journal of Food, Agriculture and Environment. 5(2):284-288.

Todd, D.K 1980. Groundwater hydrology, Second edition, 5353p, New York: John Wiley and Sons Inc.

Water Authority of Jordan (WAJ), 2009. Open Files, AmmanJordan.

World Health Organization (WHO), 1993. Guidelines for Drinking Water Quality, 2 $2^{\text {nd }}$ Edition. Vol. 1Recommendations. Geneva: 8-29 and 120-130. 


\section{الملخص العربي}

\section{تأثير التوسع العمرائ على نوعية مياه حوض وادي العوب-الأردن}

ركاد عايد طعانى

مياه الصرف الصحي المعالجة الخارجة من حطة اربد والواقعة في المنطقة العلوية من الحوض على نوعية المياه الجوفية وتصنيف نوعية مياه الينابيع والآبار وفقا لتركيبها الكيميائي. بالإضافة إلى دراسة نوعية وليه الينابيع والآبار، من الناحية الفيزيائية والكيميائية والبكتيرية. أشارت نتائج التحاليل أن العناصر الكيميائية والفيزيائية التي تتكون منها مياه الينابيع والآبار المدروسة تقع ضمن الحدود المسموح

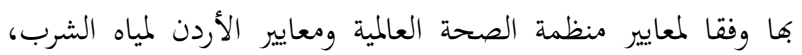

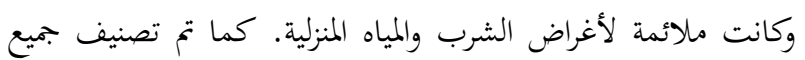
مياه الينابيع والآبار حسب تصنيف سويار ومكارتي لعسورة المياه مياه

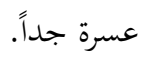
كما تم تصنيف مياه الينابيع والآبار المدروسة وفقا لتصنيف الولايات المتحدة -مختبر الملوحة، إلى مجموعتين: بجموعة نبع بروقة

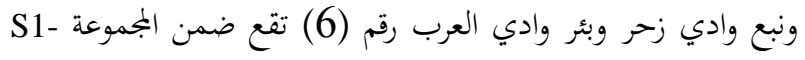

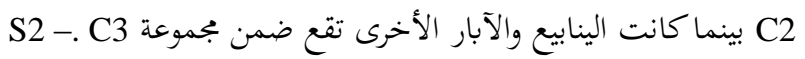

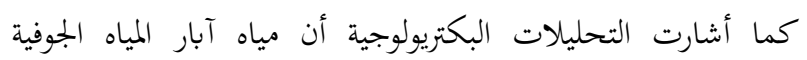

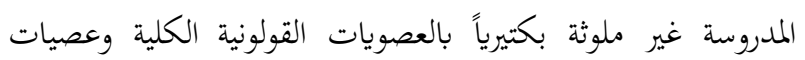

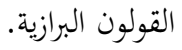

تتناول هذه الورقة البحثية الخصائص الهيدرولوجية والهيدروكيميائية لمنطقة حوض وادي العرب المائي. تبلغ مساحة منطقة الدراسة حوالي

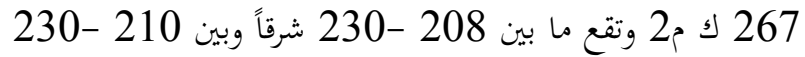
شمالاً (حسب احداثيات فلسطين). تتكشف في منطقة الدراسة الصخور الرسوبية والتي يعود عمرها، للعصر الطباشيري العلوي والعصر الثلاثي السفلى والرسوبيات الحديثة. يتراوح معدل هطول الأمطار السنوية التي تسقط على كامل حوض وادي العرب ما بين أقل من

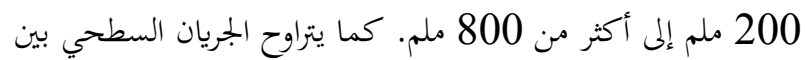

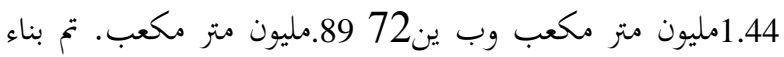

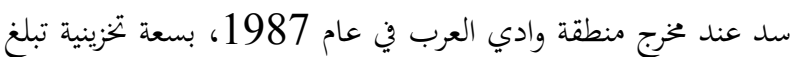
حوالي 20 مليون متر مكعب تتكون من حجم الفيضانات التي تحصل شتاءً ومن الجريان الدائم لاستخدامه للري في منطقة وادي الأردن. تم حفر أكثر من 20 بئر مياه جوفية كما يوجد ستة ينابيع رئيسة في حوض وادي العرب، وتستخدم مياه معظم آبار المياه الجوفية

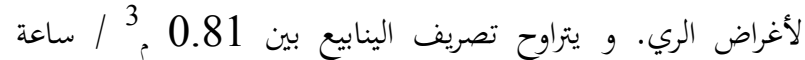

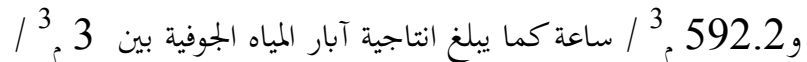
ساعة و6000 م مُ3 / ساعة. تم جمع عينات مياه من الينابيع الرئيسة الواقعة في حوض وادي العرب وعددها ستة ومن سبعة آبار مياه جوفية لدراسة تأثير تدفق 